\title{
Anti-proliferative effects of indomethacin, acemetacin and their tromethamine salts in HCT116 human colon cancer cells
}

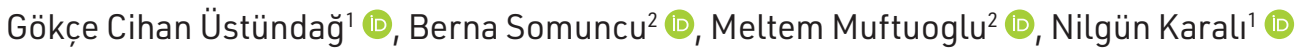 \\ ${ }^{1}$ Istanbul University, Faculty of Pharmacy, Department of Pharmaceutical Chemistry, Istanbul, Turkey \\ ${ }^{2}$ Acibadem Mehmet Ali Aydınlar University, Institute of Health Sciences, Department of Medical Biotechnology, \\ Istanbul, Turkey
}

ORCID IDs of the authors: G.C.Ü. 0000-0003-0516-6010; B.S. 0000-0002-5544-3488; M.M. 0000-0001-5372-4780; N.K. 0000-0002-6916-122X

Cite this article as: Cihan Ustundag, G., Somuncu, B., Muftuoglu, M., \& Karali, N. (2021). Anti-proliferative effects of indomethacin, acemetacin and their tromethamine salts in HCT116 human colon cancer cells. Istanbul Journal of Pharmacy, 51 (2), $161-166$.

\begin{abstract}
Background and Aims: Since 1980's, several preclinical studies have been published on the anti-colorectal cancer activity of the nonsteroidal anti-inflammatory drug indomethacin. The direct anti-proliferative effect of indomethacin seems to occur via a variety of reported COX-independent mechanisms. Acemetacin is a glycolic acid ester derivative of indomethacin and contrary to indomethacin, there is not much published research on anti-cancer effects of acemetacin. Herein, we compared the in vitro anti-proliferative properties of indomethacin, acemetacin, and their tromethamine salts in HCT116 colon cancer cells.

Methods: The tromethamine salts of indomethacin and acemetacin were synthesized and the structures were established by microanalysis, IR, ${ }^{1} \mathrm{H}-\mathrm{NMR},{ }^{13} \mathrm{C}-\mathrm{NMR}$ (APT) and 2D-NMR (HSQC and HMBC) spectrometry. Cell proliferation assays were performed using XCELLigence real-time cell analysis system.

Results: Indomethacin exhibited profound inhibitory effects with $\mathrm{IC}_{50}$ values at low micromolar ranges. Acemetacin exhibited far lower cytotoxic activity as compared to that of indomethacin. Surprisingly, indomethacin-tromethamine salt was 2-fold and 4.4-fold more potent than indomethacin at 48 and $72 \mathrm{~h}$, respectively, while maintaining its activity at $24 \mathrm{~h}$. The tromethamine salt of acemetacin was more potent than acemetacin at $24 \mathrm{~h}$ and $48 \mathrm{~h}$ post-treatment.

Conclusion: The anti-proliferative effect of indomethacin in HCT116 cells was found to be at low micro-molar levels. The esterification of indomethacin with glycolic acid caused a strong decrease in anti-proliferative effect. The salt formation caused a positive effect on the anti-proliferative activity of indomethacin and indomethacin-tromethamine salt may be a promising candidate for additional in vivo studies.
\end{abstract}

Keywords: Indomethacin, acemetacin, tromethamine, HCT116, anti-cancer

\section{INTRODUCTION}

Substantial evidence indicates that nonsteroidal anti-inflammatory drugs (NSAIDs) possess anti-colorectal cancer (CRC) activity. Most NSAIDs inhibit proliferation and reduce the growth of CRC cells in vitro, and many NSAIDs also slow tumor growth and suppress the formation of colorectal tumors in animal models and clinical studies (Ettarh, Cullen \& Calamai,
2010). However, the molecular mechanisms underlying the anti-cancer effects of NSAIDs remain unclear, and they are a matter of ongoing debate.

In the early 1980's Waddell and co-workers reported that indomethacin, a member of NSAIDs, caused regression of colorectal polyps in patients with desmoid tumors (Waddell \& Gerner, 1980; Waddell, Gerner \& Reich, 1983). Since then, numerous in 
vitro and in vivo preclinical studies have established that indomethacin has anti-CRC activity (Hull, Gardner \& Hawcroft, 2003; Hawcroft, Gardner \& Hull, 2003; Seetha, Devaraj \& Suthandiran 2020). The anti-proliferative effect of indomethacin may not be directly related to its ability to inhibit cyclooxygenase enzymes (COX-1 and COX-2) because the cell lines that do not express COX (e.g. HCT116, HCT15) have been also found to be sensitive to indomethacin (Ettarh et al., 2010). The direct anti-proliferative effect of indomethacin against cancer cells seems to occur via a variety of reported COX-independent mechanisms, including induction of apoptotic pathways (Jana, 2008; Cheng, Zhang, Li \& Lin, 2013; Qin et al., 2015; Curry et al., 2019), inhibition of angiogenesis (Golab et al., 2000), effects on cell cycling (Smith, Hawcroft \& Hull, 2000; Xu \& Zhang, 2005) and suppression of reactive oxygen species (Giardina \& Inan, 1998). The use of indomethacin is limited due to the risks of ulceration and bleeding in the gastrointestinal tract. The potentially serious adverse effects of indomethacin have prompted the researchers to develop new ester/amide derivatives with enhanced anti-infammatory efficacy and reduced gastrotoxicity (Hull et al., 2003). In 2013, Zhou et al. evaluated the anti-cancer efficacy of a new ester derivative of indomethacin, phospho-tyrosolindomethacin. The esterification has been found to enhance the anti-cancer efficacy of indomethacin against colon, breast and lung cancer cells in vitro (Zhou et al., 2013).

Acemetacin is a glycolic acid ester derivative of indomethacin, used for the treatment of inflammation and pain in many countries. Its main advantage is to produce significantly less gastric damage than indomethacin. Acemetacin is regarded as the prodrug of indomethacin, and its pharmacological effects have been attributed to its hepatic conversion to indomethacin (Chávez-Piña et al., 2007). However, different experimental studies have demonstrated that acemetacin could exert pharmacological activities independent of biotransformation to indomethacin (Chávez-Piña et al., 2007; Tavares \& Bennett, 1993). To our knowledge, contrary to indomethacin, there is not much published research on anti-cancer effects of acemetacin. In two reports published in 1993 and 1995, acemetacin was described to have anti-cancer activity in mice bearing colon 26 carcinoma and cause apoptosis in chicken embryo fibroblasts, respectively (Kisara et al., 1993; Lu et al.,1995).

Herein, we compared the in vitro cytotoxic properties of indomethacin (I) and acemetacin (A) in HCT116 colon cancer cells using xCELLigence real-time cell analysis system. The xCELLigence system allows monitoring cell viability and toxicity continuously, and thereby providing true monitoring of molecular and biochemical pathways regulating them. This system is precise and convenient to identify proliferation and cytotoxicity kinetics of HCT116 cells in real-time. It is very sensitive to determine time-dependent $I C_{50}$ values. Further, we have prepared the tromethamine salts of these two drugs (I-T and A-T) and investigated their anti-cancer efficiencies on HCT116 colon cancer cells to see if the salt forms maintain the biological activity. Salt formation is the most common and efficient method to increase aqueous solubility and dissolution rates of pharmaceutically active small molecules. The modification of physical and chemical properties by salt formation may lead to changes in biological effects (Serajuddin, 2007). Tromethamine (T) is an amino sugar that has a widespread use in organic salt formation due to its excellent safety profile and tolerability. It is commonly found as an excipient in formulations for parenteral, oral, ophthalmic and topical drug administrations (Saal \& Becker, 2013; Bookwala et al., 2018).

\section{MATERIALS AND METHODS}

\section{Chemistry}

Indomethacin (I) $\left(\mathrm{C}_{19} \mathrm{H}_{16} \mathrm{ClNO}_{4}, \mathrm{MW}: 357.79 \mathrm{~g} / \mathrm{mol}\right)$ was provided by Deva Pharmaceutical Company (Turkey). Acemetacin (A) $\left(\mathrm{C}_{21} \mathrm{H}_{18} \mathrm{ClNO}_{6}, \mathrm{MW}: 415.82 \mathrm{~g} / \mathrm{mol}\right)$ and tromethamine $(\mathbf{T})$ $\left(\mathrm{C}_{4} \mathrm{H}_{12} \mathrm{NO}_{3}, \mathrm{MW}: 121.14 \mathrm{~g} / \mathrm{mol}\right)$ were purchased from SigmaAldrich. Melting points were determined in open capillary tubes with a Buchi B-540 melting point apparatus and were not corrected. Microanalyses were performed on a Leco CHNS 932 (St. Joseph, MI, USA) elemental analyzer. IR spectra were recorded in $\mathrm{KBr}$ discs (wavenumber/ $\mathrm{cm}^{-1}$ ) on a Shimadzu IRAffinity-1 FTIR spectrophotometer. ${ }^{1} \mathrm{H}-\mathrm{NMR}\left(\mathrm{DMSO}-\mathrm{d}_{6}\right),{ }^{13} \mathrm{CNMR}$ (APT) $\left(\mathrm{DMSO}-\mathrm{d}_{6}\right)$ and heteronuclearcorrelation ${ }^{1} \mathrm{H}-{ }^{13} \mathrm{C}$ (HSQC, $\mathrm{HMBC}$ ) (DMSO- $\mathrm{d}_{6}$ ) spectra were run on Bruker AVANCE (500 $\mathrm{MHz}$ ) instrument. Chemical shifts are reported as $\delta(\mathrm{ppm})$ relative to TMS as internal standard and coupling constants $(J)$ are given in hertz $(\mathrm{Hz})$ (ar.:aromatic, al.: aliphatic, ind.:indole, tr.:tromethamine, ph.:phenyl).

Indomethacin tromethamine salt (I-T). To a solution of I (5.0 $\mathrm{mmol}$ ) in hot ethanol $(20 \mathrm{~mL}), \mathbf{T}(5.0 \mathrm{mmol})$ was added and the mixture was heated at $80{ }^{\circ} \mathrm{C}$ for 30 min with stirring. Excess ethanol was evaporated and the resulting residue was recrystallized from ethanol: White powder (66\%); mp 147-150 $\mathrm{C}_{\text {; }}$ IR(KBr): $U_{\max }$ 3345, 3273 (O-H), 3096, 3061, 3034 (ar. C-H), 2997, 2958, 2935, 2895, 2835 (al. $\mathrm{C}-\mathrm{H}$ and $\mathrm{NH}_{3}{ }^{+}(\mathrm{N}-\mathrm{H})$ ), 1670 (amide $\mathrm{C}=\mathrm{O}), 1599$ (carboxylate anion $\mathrm{C}=\mathrm{O}$ ); ${ }^{1} \mathrm{H}-\mathrm{NMR}$ (DMSO- $\mathrm{d}_{6} / 500$ $\mathrm{MHz}): \delta 2.19\left(3 \mathrm{H}, \mathrm{s}, 2-\mathrm{CH}_{3}\right.$-ind.), $3.37\left(7 \mathrm{H}, \mathrm{s}, \mathrm{CH}_{2}\right.$-tr. with $\left.\mathrm{H}_{2} \mathrm{O}\right)$, $3.43\left(2 \mathrm{H}, \mathrm{s}, 3-\mathrm{CH}_{2} \mathrm{COO}-\right.$ ind $), 3.75\left(3 \mathrm{H}, \mathrm{s}, 5-\mathrm{OCH}_{3}\right.$-ind.), $5.77(1 \mathrm{H}$, s, OH-tr.), 6.68 (1H, dd, J=9.0, 2.5, H6-ind.), $6.93(1 \mathrm{H}, \mathrm{d}, J=9.0, \mathrm{H7}-$ ind.), $7.05(1 \mathrm{H}, \mathrm{d}, \mathrm{J}=2.5, \mathrm{H} 4$-ind.), 7.64 ( $2 \mathrm{H}, \mathrm{d}, \mathrm{J}=8.7, \mathrm{H3}, 5-\mathrm{ph}$.), $7.67\left(2 \mathrm{H}, \mathrm{d}, \mathrm{J}=8.7, \mathrm{H} 2,6-\right.$ ph.), $8.33\left(1 \mathrm{H}, \mathrm{s}, \mathrm{NH}_{3}{ }^{+}\right.$-tr.) $){ }^{13} \mathrm{C}-\mathrm{NMR}$ (APT, HSQC, HMBC) (DMSO-d $/ 125 \mathrm{MHz}): \delta 13.86$ (2- $\mathrm{CH}_{3}$-ind.), 32.73 (3- $\mathrm{CH}_{2} \mathrm{COO}$-ind.), 55.78 (5-OCH${ }_{3}$-ind.), 59.98 (C-tr.), $61.09\left(\mathrm{CH}_{2}^{-}\right.$ tr.), 102.51 (C4-ind.), 111.46 (C6-ind.), 114.90 (C7-ind.), 116.72 (C3-ind.), 129.49 (C3,5-ph.), 130.69 (C7a-ind.), 131.53 (C2,6-ph.), 131.92 (C3a-ind.), 134.50 (C1-ph.), 134.91 (C2-ind.), 137.84 (C4ph.), 155.88 (C5-ind.), 168.28 (N-CO), 174.30 (CO-O). Anal. Calcd for $\mathrm{C}_{23} \mathrm{H}_{27} \mathrm{ClN}_{2} \mathrm{O}_{7}$ (478.92): C, 57.68; $\mathrm{H}, 5.68 ; \mathrm{N}, 5.85$. Found: $\mathrm{C}$, 57.79; $\mathrm{H}, 5.76 ; \mathrm{N}, 6.10$.

Acemetacin tromethamine salt $(\boldsymbol{A}-\mathbf{T})$. T $(5.0 \mathrm{mmol})$ was added to a solution of $\mathbf{A}(5.0 \mathrm{mmol})$ in hot ethanol $(20 \mathrm{~mL})$ and the mixture was heated at $80{ }^{\circ} \mathrm{C}$ for $30 \mathrm{~min}$ with stirring. Excess ethanol was evaporated and the resulting residue was recrystallized from ethanol White powder (75\%); mp 181-184 ${ }^{\circ} \mathrm{C}$; IR(KBr): $U_{\max } 3317,3211(\mathrm{O}-\mathrm{H}), 3088,3074$ (ar. C-H), 2945, 2922, 2887, 2839 (al. $\mathrm{C}-\mathrm{H}$ and $\mathrm{NH}_{3}{ }^{+}(\mathrm{N}-\mathrm{H})$ ), 1715 (ester $\mathrm{C}=\mathrm{O}$ ), 1697 (amide $\mathrm{C}=\mathrm{O}$ ), 1616 (carboxylate anion $\mathrm{C}=\mathrm{O}$ ); ${ }^{1} \mathrm{H}-\mathrm{NMR}$ (DMSO-d 6 /500 MHz): $\delta 2.21\left(3 \mathrm{H}, \mathrm{s}, 2-\mathrm{CH}_{3}\right.$-ind.), $3.44\left(7 \mathrm{H}, \mathrm{s}, \mathrm{CH}_{2}^{-}\right.$ tr. with $\left.\mathrm{H}_{2} \mathrm{O}\right), 3.77,3.78\left(5 \mathrm{H}, 2 \mathrm{~s}, 3-\mathrm{CH}_{2} \mathrm{COOCH}_{2} \mathrm{COO}\right.$-ind. and 5- $\mathrm{OCH}_{3}$-ind. $), 4.26\left(2 \mathrm{H}, \mathrm{s}, 3-\mathrm{CH}_{2} \mathrm{COOCH}_{2} \mathrm{COO}^{-}\right.$-ind.), $5.79(1 \mathrm{H}, \mathrm{s}$, 
OH-tr.), 6.70 (1H, dd, J=9.0, 2.5, H6-ind.), $6.95(1 \mathrm{H}, \mathrm{d}, \mathrm{J}=9.0, \mathrm{H} 7-$ ind.), $7.10(1 \mathrm{H}, \mathrm{d}, \mathrm{J}=2.5, \mathrm{H} 4-\mathrm{ind}$.), $7.65(2 \mathrm{H}, \mathrm{d}, \mathrm{J}=8.6, \mathrm{H} 3,5-\mathrm{ph}$.), $7.69(2 \mathrm{H}, \mathrm{d}, \mathrm{J}=8.6, \mathrm{H} 2,6-\mathrm{ph}),. 8.32\left(1 \mathrm{H}, \mathrm{s}, \mathrm{NH}_{3}{ }^{+}\right.$-tr. $) ;{ }^{13} \mathrm{C}-\mathrm{NMR}$ (APT, HSQC, HMBC) (DMSO-d $/ 125 \mathrm{MHz}): \delta 13.77$ (2- $\mathrm{CH}_{3}$-ind.), 29.84 (3- $\mathrm{CH}_{2} \mathrm{COOCH}_{2}$-ind.), 55.87 (5- $\mathrm{OCH}_{3}$-ind.), 60.12 (C-tr.), 61.02 $\left(\mathrm{CH}_{2}\right.$-tr.), 63.73 (3- $\mathrm{CH}_{2} \mathrm{COOCH}_{2}$-ind.), 102.11 (C4-ind.), 112.07 (C6-ind.), 113.55 (C3-ind.), 114.99 (C7-ind.), 129.51, 129.54 (C3,5ph.), 130.60 (C7a-ind.), 131.14 (C3a-ind.), 131.65, 131.68 (C2,6ph.), 134.62 (C1-ph.), 135.74 (C2-ind.), 138.06 (C4-ph.), 156.05 (C5-ind.), 168.35 (3- $\mathrm{CH}_{2} \mathrm{COOCH}_{2}$-ind.), 170.64 (N-CO), 170.80 (CO-O). Anal. Calcd for $\mathrm{C}_{25} \mathrm{H}_{29} \mathrm{ClN}_{2} \mathrm{O}_{9}$ (536.96): C, 55.92; $\mathrm{H}, 5.44$; N, 5.22. Found: C, 55.86; H, 5.42; N, 5.46.

\section{In vitro anti-proliferative assay using the xCELLigence DP system}

HCT116 (human colon cancer) cell line was purchased from the American Type Culture Collection (ATCC). HCT116 cells were grown in DMEM (Gibco-Life Technologies) supplemented with 10\% fetal bovine serum (Gibco-Life Technologies) and 1\% Pen/ Strep (Gibco-Life Technologies) at $37^{\circ} \mathrm{C}, 5 \% \mathrm{CO}_{2}$ incubator.

Impedance-based real time detection of cell proliferation and cytotoxicity experiments were performed according to the instruction manual of the xCELLigence DP system (ACEA Biosciences Inc.). After determining the optimum HCT116 cell number from its proliferation pattern, 15000 HCT116 cells/ well were seeded in E-Plate. Approximately $20 \mathrm{~h}$ after seeding, when the cells were in the log growth phase, HCT116 cells were treated with different concentrations of I, I-T, A, and A-T as indicated in the figure legends and monitored for every 30 min for $93 \mathrm{~h}$. The cells were treated with a final concentration of $0.01 \%$ DMSO served as a vehicle control. The results were expressed by cell index (Cl). The RTCA software was used to calculate $I_{50}$ values from dose response curve.

\section{RESULTS AND DISCUSSION}

\section{Chemistry}

Briefly, I and A were treated with tromethamine in hot ethanol, and the mixture was heated under reflux with stirring to generate the desired tromethamine salts (Figure 1). The structures of I-T and A-T were established by microanalysis, IR, ' $\mathrm{H}-\mathrm{NMR}$, ${ }^{13} \mathrm{C}-\mathrm{NMR}$ (APT) and 2D-NMR (HSQC and HMBC) spectrometry. I-T was previously synthesized in different studies, and the melting point and spectroscopic data were consistent with the findings of previous reports (Bookwala et al., 2018; Kahan, 1985). A-T was synthesized and characterized for the first time in this study, according to our knowledge.

\section{In vitro anti-proliferative activity}

Figure 2 shows the real time dynamic monitoring of HCT116 cell proliferation and the compound induced cytotoxicity with xCELLigence system. To explore the potential role of $\mathbf{I}, \mathbf{A}, \mathbf{I - T}$ and A-T on cell proliferation, HCT116 cells were seeded at 15000 cells per well of an E-plate (Roche, ACEA Biosciences) and treated with increasing concentrations of the tested compounds when the cells were in the log growth phase. Cell growth was measured every 30 minutes for up to $96 \mathrm{~h}$ (Real-Time and Dynamic Monitoring of Cell Proliferation and Viability for Adherent Cells. http://www.aceabio.com/wpcontent/uploads/Monitoring-Cell-Proliferation-and-Viabilityfor-Adherent-Cells.pdf., 2013). As shown in Figure 2, treatment of HCT116 cells with the increasing concentration of $\mathbf{I}, \mathbf{A}, \mathbf{I - T}$ and $\mathbf{A}-\mathbf{T}$ induced a dose-dependent cytotoxicity on HCT116<smiles>COc1ccc2c(c1)c(CC(=O)[O-])c(C)n2C(=O)c1ccc(Cl)cc1</smiles>

Figure 1. Chemical structures of tromethamine salts (I-T and $\mathbf{A}-\mathbf{T})$ of indomethacin (I) and acemetacin (A).

Table 1. IC $\mathrm{C}_{50}$ a values of indomethacin (I), acemetacin (A) and their tromethamine salts (I-T and AT) determined with the RTCA ${ }^{\mathrm{b}}$ system after 24,48 and $72 \mathrm{~h}$ treatments in HCT116 cells.

\begin{tabular}{|c|c|c|c|}
\hline Compound & $\begin{array}{l}24 \mathrm{~h} \\
\mathrm{IC} C_{50}\end{array}$ & $\begin{array}{l}48 \mathrm{~h} \\
\mathrm{IC} C_{50}\end{array}$ & $\begin{array}{l}72 \mathrm{~h} \\
\mathrm{IC} \mathrm{C}_{50}\end{array}$ \\
\hline I & $22.81 \mu \mathrm{M}$ & $133.55 \mu \mathrm{M}$ & $375.39 \mu \mathrm{M}$ \\
\hline$I-T$ & $27.52 \mu \mathrm{M}$ & $62.50 \mu \mathrm{M}$ & $85.68 \mu \mathrm{M}$ \\
\hline A & $259.56 \mu \mathrm{M}$ & $110.00 \mathrm{mM}$ & $1.02 \mathrm{mM}$ \\
\hline$A-T$ & $183.50 \mu \mathrm{M}$ & $58.80 \mathrm{mM}$ & $329.00 \mathrm{mM}$ \\
\hline
\end{tabular}

a The half maximal inhibitory concentration for dose-response curves, ${ }^{\mathrm{b}}$ Real time cell analyze, ${ }^{*}$ The experiments were performed in triplicate. 
A

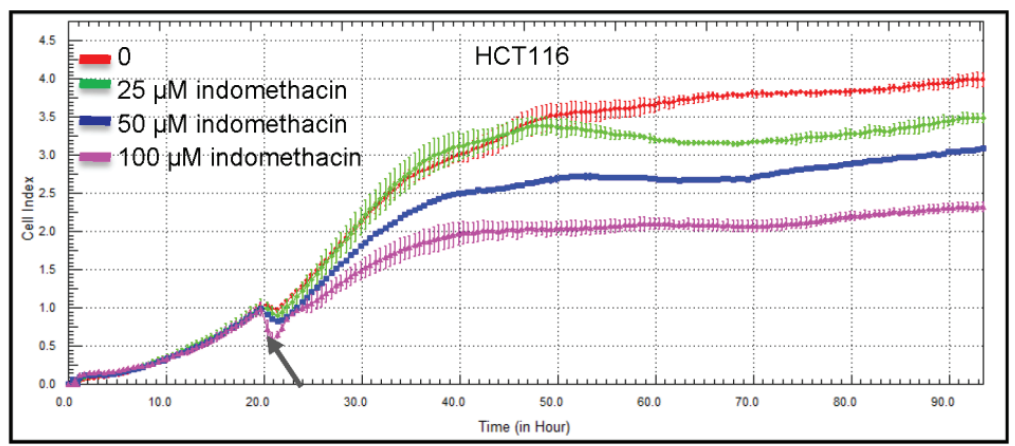

B

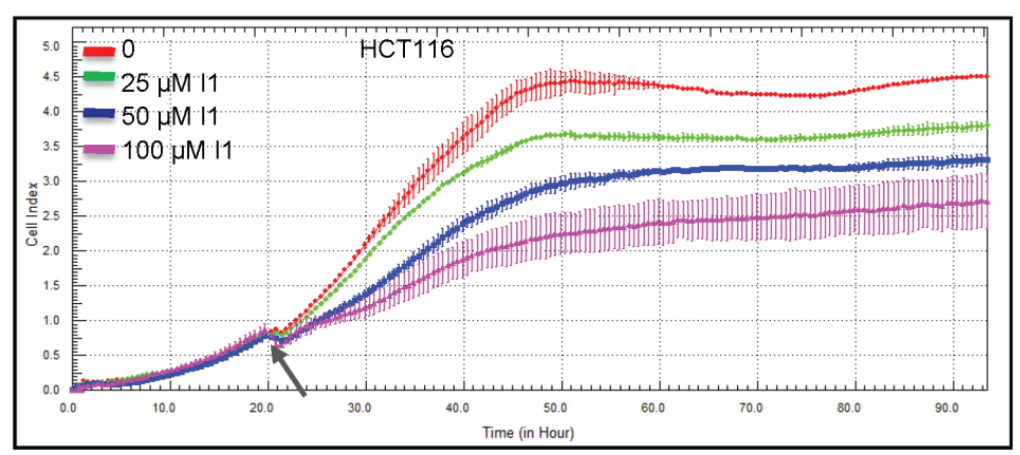

C

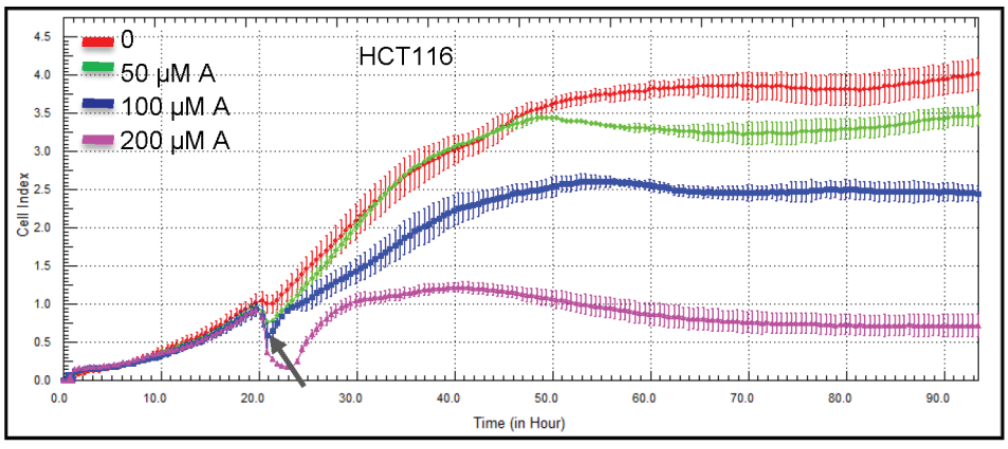

D

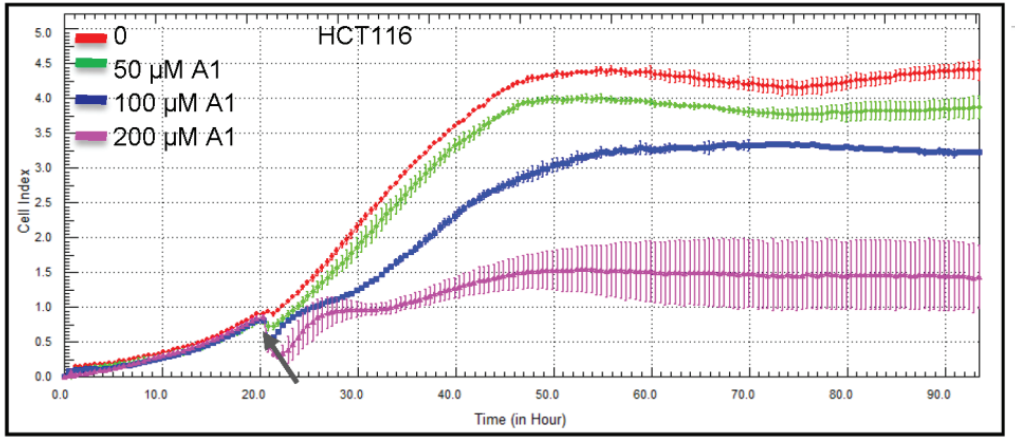

Figure 2. Cytotoxic effects of I (A), I-T (B), A (C) A-T (D) on HCT116 cells. Grey arrow indicates the time of addition of the compounds.

cells. Compound induced cytotoxicity in HCT116 cells was further quantified using the XCELLigence real time cell analyze (RTCA) software to determine $I C_{50}$ values calculated at three specific post-treatment times, 24,48 and $72 \mathrm{~h}$ (Table 1). It is expected to see time-dependent decrease in $I_{50}$ values, but it also depends on the mechanism of each compound in specific cell type. The time- dependent increase was observed on $\mathrm{IC}_{50}$ values of $\mathbf{I}$ and $\mathbf{I}-\mathbf{T}$ whereas the time-dependent decrease was observed on IC ${ }_{50}$ values of $\mathbf{A}$ and $\mathbf{A}$-T on HCT116 cells (except for compound $\mathbf{A}$-T at 72 h) (Table 1). 
The anti-proliferative effect of I on HCT116 cells was found to be at low (micro-molar) levels, as consistent with previous studies on anti-CRC activity of I (Hull et al., 2003). The esterification of I with glycolic acid (chain elongation) caused a strong decrease in anti-proliferative effect. The cytotoxic activity of $\mathbf{I}$ was approximately 10 to 1000-fold superior compared to the ester analogue. Surprisingly, salt formation caused a positive effect on activity. I-T was 2-fold and 4.4-fold more potent than I at 48 and 72 h, respectively, while maintaining activity at $24 \mathrm{~h}$. A-T was found to induce cytotoxicity at millimolar concentrations at 48 and $72 \mathrm{~h}$ post-treatments as its precursor $\mathbf{A}$ (Figure 2 and Table 1). Comparing $\mathbf{I}$ and $\mathbf{I - T}$, deprotonated form of carboxylic acid residue could lead to an increase in anti-proliferative and cytotoxic properties on HCT116 colon cancer cells.

\section{CONCLUSIONS}

We have compared the in vitro anti-CRC activity of $\mathbf{I}$ and its carboxymethyl ester $\mathbf{A}$ by real-time monitoring of HCT116 cells. I exhibited profound inhibitory activity with $I_{50}$ values at micromolar ranges. Ester formation with glycolic acid led to a dramatic decrease in biological activity, and $\mathbf{A}$ exhibited far lower cytotoxic activity as compared to that of $\mathbf{I}$. We have further synthesized the tromethamine salts of $\mathbf{I}$ and $\mathbf{A}$ to investigate the effect of salt formation on the anti-CRC activity. The in vitro screening results revealed that salification could change the biological activity of $\mathbf{I}$. I-T exhibited a significant anti-proliferative effect superior to $\mathbf{I}$ itself and may be a promising candidate for additional in vivo studies.

Peer-review: Externally peer-reviewed.

Author Contributions: Conception/Design of Study- N.K., M.M.; Data Acquisition- G.C.Ü., B.S.; Data Analysis/Interpretation- G.C.Ü., B.S., M.M., N.K.; Drafting Manuscript- G.C.Ü., M.M.; Critical Revision of Manuscript- G.C.Ü., B.S., M.M., N.K.; Final Approval and AccountabilityG.C.Ü., B.S., M.M., N.K.

Conflict of Interest: The authors have no conflict of interest to declare.

Financial Disclosure: This work was supported by the Scientific and Technological Research Council of Turkey (TUBITAK; grant numbers: 212T026 and 215S614)

\section{REFERENCES}

- Bookwala, M., Thipsay, P., Ross, S., Zhang, F., Bandari, S., \& Repka, M. A. (2018). Preparation of a crystalline salt of indomethacin and tromethamine by hot melt extrusion technology. European Journal of Pharmaceutics and Biopharmaceutics, 131, 109-119. http:// dx.doi.org/10.1016/j.ejpb.2018.08.001.

- Chávez-Piña, A. E., McKnight, W., Dicay, M., Castañeda-Hernández, G., \& Wallace, J. L. (2007). Mechanisms underlying the antiinflammatory activity and gastric safety of acemetacin. British Journal of Pharmacology, 152, 930-938. http://dx.doi.org/10.1038/ sj.bjp.0707451.

- Cheng, Y. L., Zhang, G. Y., Li, C., \& Lin, J. (2013). Screening for novel protein targets of indomethacin in HCT116 human colon cancer cells using proteomics. Oncology Letters, 6, 1222-1228. http:// dx.doi.org/10.3892/ol.2013.1560.
Curry, J. M., Besmer, D. M., Erick, T. K., Steuerwald, N., Das Roy, L., Grover, P., Rao, S., Nath, S., Ferrier J. W., Reid, R. W. \& Mukherjee, P. (2019). Indomethacin enhances anti-tumor efficacy of a MUC1 peptide vaccine against breast cancer in MUC1 transgenic mice. PLOS ONE, 14(11), e0224309. https://doi.org/10.1371/journal.pone.0224309.

- Ettarh, R., Cullen, A., \& Calamai, A. (2010). NSAIDs and cell proliferation in colorectal cancer. Pharmaceuticals, 3, 2007-2021. http:// dx.doi.org/10.3390/ph3072007.

Giardina, C., \& Inan, M. S. (1998). Nonsteroidal anti-inflammatory drugs, short-chain fatty acids, and reactive oxygen metabolism in human colorectal cancer cells. Biochimica et Biophysica Acta, 1401, 277-288. http://dx.doi.org/10.1016/s0167-4889(97)00140-7.

- Gołab, J., Kozar, K., Kamiński, R., Czajka, A., Marczak, M., Świtaj, T. ... Jakóbisiak, K. M. (2000). Interleukin 12 and indomethacin exert a synergistic, angiogenesis-dependent antitumor activity in mice. Life Sciences, 66, 1223-1230. http://dx.doi.org/10.1016/s00243205(00)00427-6.

- Hawcroft, G., Gardner, S. H., \& Hull, M. A. (2003). Activation of peroxisome proliferator-activated receptor $\gamma$ does not explain the antiproliferative activity of the nonsteroidal anti-inflammatory drug indomethacin on human colorectal cancer cells. Journal of Pharmacology and Experimental Therapeutics, 305, 632-637. http://dx.doi.org/10.1124/jpet.103.048769.

- Hull, M. A., Gardner, S. H., \& Hawcroft, G. (2003). Activity of the non-steroidal anti-inflammatory drug indomethacin against colorectal cancer. Cancer Treatment Reviews, 29, 309-320. http:// dx.doi.org/10.1016/S0305-7372(03)00014-8.

Jana, N. R. (2008). NSAIDs and apoptosis. Cellular and Molecular Life Sciences, 65, 1295-1301. http://dx.doi.org/10.1007/s00018008-7511-x.

- Kahan, A. (1985). Watersoluble derivatives of non-steroidal antiinflammatory agents and a process for the production thereof. US Patent 4,518,608.

- $\quad$ Kisara, S., Maekawa, I., Sasaki, K., Suzuki, N., Hayashi, A., Furusawa, S., Takayanagi, Y., \& Sasaki, K. (1993). Antitumor activity of acemetacin in mice bearing colon 26 carcinoma: a preliminary report. Research Communications in Chemical Pathology and Pharmacology, 81, 247-250.

- $\quad$ Lu, X., Xie, W., Reed, D., Bradshaw, W. S., \& Simmons, D. L. (1995). Nonsteroidal antiinflammatory drugs cause apoptosis and induce cyclooxygenases in chicken embryo fibroblasts. Proceedings of the National Academy of Sciences of the United States of America (PNAS), 92, 7961-7965. http://dx.doi.org/10.1073/pnas.92.17.7961. Qin, S., Xu, C., Li, S., Yang, C., Sun, X., Wang, X., Tang, S. C., \& Ren, H. (2015). Indomethacin induces apoptosis in the EC109 esophageal cancer cell line by releasing second mitochondria-derived activator of caspase and activating caspase-3. Molecular medicine reports, 11,4694-4700. https://doi.org/10.3892/mmr.2015.3331.

Real-Time and Dynamic Monitoring of Cell Proliferation and Viability for Adherent Cells. xCelligence System Application Note No. 1. (2013, January). Retrieved from http://www.aceabio.com/ wp-content/uploads/Monitoring-Cell-Proliferation-and-Viabilityfor-Adherent-Cells.pdf.

- Saal, C., \& Becker, A. (2013). Pharmaceutical salts: a summary on doses of salt formers from the Orange Book. European Journal of Pharmaceutical Sciences, 49, 614-623. http://dx.doi.org/10.1016/j. ejps.2013.05.026.

- Seetha, A., Devaraj, H., \& Sudhandiran, G. (2020). Indomethacin and juglone inhibit inflammatory molecules to induce apoptosis in colon cancer cells. Journal of biochemical and molecular toxicology, 34(2), e22433. https://doi.org/10.1002/jbt.22433.

Serajuddin, A. T. (2007). Salt formation to improve drug solubility. Advanced Drug Delivery Reviews, 59, 603-616. http://dx.doi. org/10.1016/j.addr.2007.05.010. 
- Smith, M. L., Hawcroft, G., \& Hull, M. A. (2000). The effect of nonsteroidal anti-inflammatory drugs on human colorectal cancer cells: evidence of different mechanisms of action. European Journal of Cancer, 36, 664-674. http://dx.doi.org/10.1016/s09598049(99)00333-0.

- Tavares, I. A., \& Bennett, A. (1993). Acemetacin and indomethacin: differential inhibition of constitutive and inducible cyclo-oxygenases in human gastric mucosa and leucocytes. International Journal of Tissue Reactions, 15, 49-53.

- Waddell, W. R., \& Gerner, R. E. (1980). Indomethacin and ascorbate inhibit desmoid tumors. Journal of Surgical Oncology, 15, 85-90. http://dx.doi.org/10.1002/jso.2930150113.
- Waddell, W. R., Gerner, R. E., \& Reich, M. P. (1983). Nonsteroid antiinflammatory drugs and tamoxifen for desmoid tumors and carcinoma of the stomach. Journal of Surgical Oncology, 22, 197-211. http://dx.doi.org/10.1002/jso.2930220314.

- $\quad$ Xu, M. H., \& Zhang, G. Y. (2005). Effect of indomethacin on cell cycle proteins in colon cancer cell lines. World Journal of Gastroenterology, 11, 1693-1696. http://dx.doi.org/10.3748/wjg.v11.i11.1693.

Zhou, D., Papayannis, I., Mackenzie, G. G., Alston, N., Ouyang, N., Huang, L. ... Rigas, B. (2013). The anticancer effect of phosphotyrosol-indomethacin (MPI-621), a novel phosphoderivative of indomethacin: In vitro and in vivo studies. Carcinogenesis, 34, 943951. http://dx.doi.org/10.1093/carcin/bgs394. 